\title{
Quantitative Analysis of Factors Influencing Late Lumen Loss and Restenosis After Directional Coronary Atherectomy
}

\author{
Jeffrey J. Popma, MD, Nicoletta B. De Cesare, MD, Cass A. Pinkerton, MD, \\ Dean J. Kereiakes, MD, Patrick Whitlow, MD, Spencer B. King III, MD, Eric J. Topol, MD, \\ David R. Holmes, MD, Martin B. Leon, MD, and Stephen G. Ellis, MD
}

Although encouraging initial results have been demonstrated after directional atherectomy, the mechanisms and predictors of late lumen loss and restenosis after this procedure have not been evaluated. To examine these issues, clinical and angiographic follow-up were obtained in 262 (96\%) and 212 (77\%) of 274 patients undergoing successful directional coronary atherectomy. Symptom recurrence developed in 87 (33\%) patients and angiographic restenosis was found in 93 (44\%). Restenosis was highest in restenotic lesions in saphenous vein grafts ( $78 \%$ [95\% confidence interval (CI): 56 to 100\%]) and lowest in new-onset lesions in the left anterior descending (27\% [95\% Cl: 15 to $39 \%$ ]) and circumflex (14\% [95\% Cl: 0 to 43\%]) coronary arteries. Residual Iumen diameter immediately after atherectomy was smaller in re-stenotic lesions $(p=0.002)$ and in lesions $\geq 10 \mathrm{~mm}$ in length $(p=0.02)$. Late lumen loss was associated with the minimal Iumen diameter immediately after atherectomy ( $p<0.001)$, saphenous vein graft lesion location $(p=0.008)$, and male gender $(p=0.02)$. Restenotic lesions ( $p<0.001$ ), lesions $\geq 10 \mathrm{~mm}$ in length ( $p=0.018)$, saphenous vein graft lesion location $(p=0.025)$ and male gender $(p=0.045)$ were independent predictors for restenosis. It is concluded that restenosis after directional atherectomy is related both to factors resulting in a suboptimal initial result and to factors contributing to excessive late lumen loss. These results may have implications for lesion selection in patients undergoing directional coronary atherectomy.

(Am J Cardiol 1993;71:552-557)

From the Departments of Internal Medicine (Cardiology Divisions) of the Washington Hospital Center, Washington, D.C., University of Michigan, Ann Arbor, Michigan, St. Vincent's Hospital, Indianapolis, Indiana, Christ Hospital, Cincinnati, Ohio, The Cleveland Clinic, Cleveland, Ohio, Emory University, Atlanta, Georgia, and the Mayo Clinic, Rochester, Minnesota. Manuscript received July 10, 1992; revised manuscript received and accepted September 24, 1992.

Address for reprints: Jeffrey J. Popma, MD, Washington Hospital Center, 1100 Irving Street, N.W. Suite 4B-14, Washington, D.C. 20010.
A variety of investigational angioplasty devices have been used in an attempt to reduce the incidence of restenosis after coronary angioplasty, ${ }^{1-5}$ although with somewhat limited success.2,45 Angiographic restenosis has been reported in 30 to $50 \%$ of patients after directional coronary atherectomy, ${ }^{6,7}$ similar to restenosis rates for balloon angioplasty, ${ }^{8}$ despite an improved immediate angiographic result with this procedure. ${ }^{9,10}$ A recent clinical study suggests that the larger lumen dimensions initially obtained with investigational angioplasty devices may be partially offset by greater degrees of intimal hyperplasia and recoil during the follow-up period. ${ }^{11}$ To date, however, the precise clinical, angiographic and procedural factors associated with late lumen loss and restenosis after directional atherectomy remain largely undefined. To identify these factors, we reviewed the late clinical outcome of 262 patients undergoing directional atherectomy at 5 clinical centers. Cineangiograms, obtained in 212 patients $(77 \%)$ before, immediately after and late (0.5 to 15.8 months) after directional atherectomy, were analyzed using qualitative morphologic and quantitative angiographic methods. The determinants of late lumen loss and restenosis were then examined.

\section{METHODS}

Patient population: From June 1988 to May 1990 , directional coronary atherectomy was performed in 318 procedures ( 305 patients) at 5 clinical sites (Appendix). Proximal lesions and lesions with marked eccentricity or irregularity within coronary arteries or saphenous vein grafts of sufficient caliber to allow passage of the atherectomy device $(\geq 2.5 \mathrm{~mm})$ were considered suitable for directional atherectomy. Procedural success, defined as $<50 \%$ residual diameter stenosis, tissue retricval, and the absence of in-hospital ischemic complications, was obtained in 274 procedures $(86 \%) .{ }^{12,13}$ Before atherectomy, all patients gave written informed consent, approved by the respective institutional review boards.

After hospital discharge, 262 palients (96\%) were followed for recurrent symptoms of angina or other clinical evidence of myocardial ischemia; the remaining 12 patients were lost to follow-up. Exercise treadmill testing was obtained 4 to 6 months after atherectomy in 174 patients $(66 \%)$, but was not performed in 88 patients (34\%) because of unstable angina, physician or patient refusal. Coronary arteriography was performed in 212 patients $(77 \%) 6.1 \pm 2.5$ months (range 0.2 to 15.8 ) after directional atherectomy. 


\begin{tabular}{|c|c|c|c|}
\hline & $\begin{array}{c}\text { No Angiographic } \\
\text { Restenosis } \\
(n=119)(\%)\end{array}$ & $\begin{array}{c}\text { Angiographic } \\
\text { Restenosis } \\
(n=93)(\%)\end{array}$ & $\begin{array}{l}\text { No Follow-Up } \\
\text { Arteriography } \\
(n=50)(\%)\end{array}$ \\
\hline \multicolumn{4}{|c|}{ No Symptoms of Recurrent Ischemia } \\
\hline Negative ETT & $67(56)$ & $10(11)$ & $2(4)$ \\
\hline Positive ETT & $11(9)$ & $12(13)$ & $30(60)$ \\
\hline No ETT performed & $24(20)$ & $5(5)$ & $14(28)$ \\
\hline \multicolumn{4}{|c|}{ Symptoms of Recurrent Ischemia } \\
\hline Negative ETT & $3(3)$ & $7(7)$ & $2(1)$ \\
\hline Positive ETT & $6(5)$ & $23(25)$ & $1(2)$ \\
\hline No ETT performed & $8(7)$ & $36(39)$ & $1(2)$ \\
\hline
\end{tabular}

Clinical and procedural variables: Case report forms were reviewed for selected clinical features including age, gender, angina status, and the presence of diabetes, unstable angina or a prior history of restenosis. Atherectomy device size, peak balloon inflation pressure, number of specimens excised, and number of atherectomy passes were also recorded. A positive exercise treadmill test response was defined as clinical (typical chest pain) or electrocardiographic $(>0.1 \mathrm{mV}$ ST-segment depression) evidence of ischemia during exercise stress testing.

Qualitative angiographic analysis: Cineangiograms, obtained before and after directional atherectomy, were reviewed at the University of Michigan core angiographic laboratory. Lesions were visualized in multiple projections and scored according to the presence or absence of 9 previously defined angiographic criteria. ${ }^{12,13}$ These morphologic criteria included: diffuse proximal disease, lesion eccentricity, bend $\geq 45^{\circ}$, proximal vessel tortuosity, lesion irregularity, lesion calcification, bifurcation lesion, thrombus-containing lesion, and lesion $\geq 10$ $\mathrm{mm}$ in length. The device:artery ratio was measured by calipers and defined as the ratio of the atherectomy device to the normal adjacent coronary artery for the largest device that crossed the stenosis. The presence of multivessel coronary disease was recorded after review of the cineangiograms by the principal investigators. In the 212 patients with angiographic follow-up, restenosis was defined as a residual diameter stenosis $\geq 50 \%$ at time of follow-up.

Quantitative angiographic analysis: Quantitative coronary analysis was performed in 193 lesions before, immediately after and late after directional atherectomy. In 19 lesions not suitable for quantitative analysis because of absence of an image calibration factor or poor angiographic quality in 1 or more studies, percent stenosis was calculated using digital calipers. End-diastolic cineframes, selected whenever possible from orthogonal projections, were matched before, immediately after and late after directional atherectomy. The selected cineframes were digitized using a cine-video converter, and a computer-assisted edge-detection algorithm was applied to the arterial and catheter contours. ${ }^{14}$ Using the diagnostic or guiding catheter as the calibration standard, reference and minimal lumen diameters were determined. From the orthogonal projections, average reference and minimal lesion lumen diameters before, imme-

\begin{tabular}{|c|c|c|c|}
\hline & $\begin{array}{c}\text { No } \\
\text { Restenosis } \\
(n=99)\end{array}$ & $\begin{array}{c}\text { Restenosis } \\
(\mathrm{n}=94)\end{array}$ & $\begin{array}{c}\text { Overall } \\
(\mathrm{n}=193)\end{array}$ \\
\hline \multicolumn{4}{|l|}{ Reference diameter $(\mathrm{mm})$} \\
\hline Before atherectomy & $3.5 \pm 0.6$ & $3.4 \pm 0.7$ & $3.5 \pm 0.7$ \\
\hline After atherectomy & $3.6 \pm 0.6$ & $3.4 \pm 0.7$ & $3.5 \pm 0.7$ \\
\hline Follow-up & $3.5 \pm 0.7$ & $3.5 \pm 0.7$ & $3.5 \pm 0.7$ \\
\hline \multicolumn{4}{|l|}{ Stenotic diameter $(\mathrm{mm})$} \\
\hline Before atherectomy & $1.2 \pm 0.5$ & $1.1 \pm 0.5$ & $1.1 \pm 0.5$ \\
\hline After atherectomy & $3.0 \pm 0.8$ & $2.8 \pm 0.9$ & $2.9 \pm 0.9$ \\
\hline Follow-up & $2.7 \pm 1.0$ & $1.1 \pm 0.6$ & $1.9 \pm 1.2$ \\
\hline Acute gain & $1.8 \pm 0.8$ & $1.7 \pm 0.9$ & $1.8 \pm 0.9$ \\
\hline Lale lumen loss** & $0.3 \pm 1.1$ & $1.7 \pm 1.0$ & $1.0 \pm 1.3$ \\
\hline \multicolumn{4}{|l|}{$\%$ Diameter stenosis } \\
\hline Before atherectomy & $67 \pm 13$ & $69 \pm 14$ & $68 \pm 13$ \\
\hline After atherectomy & $15 \pm 19$ & $18 \pm 22$ & $16 \pm 21$ \\
\hline Follow-up & $23 \pm 22$ & $69 \pm 13$ & $45 \pm 29$ \\
\hline Lesion length $(\mathrm{mm}) \dagger$ & $5.2 \pm 3.8$ & $7.4 \pm 5.3$ & $6.2 \pm 4.6$ \\
\hline
\end{tabular}

diately after and late after directional atherectomy were calculated. Acute gain was defined as the difference in minimal lumen diameter (in millimeters) before and immediately after directional atherectomy. Late lumen loss was defined as the loss in postprocedural minimal lumen diameter (in millimeters) during the follow-up period compared with the minimal lumen diameter immediately after the procedure. ${ }^{11}$

Statistical analysis: Continuous variables are presented as mean $\pm 1 \mathrm{SD}$; categorical variables are presented as frequencies with $95 \%$ confidence intervals (CI), where appropriate. Differences in continuous variables were analyzed using nonparametric analysis (Mann-Whitney U test), whereas differences in proportions between clinical and angiographic characteristics were assessed using chi-square test or the Fisher's exact test when $>20 \%$ of the cells had an expected value $<5$. The odds ratio was obtained by:

$\frac{\frac{\text { Probability of restenosis, variable present }}{\text { Probability of no restenosis, variable present }}}{\frac{\text { Probability of restenosis, variable absent }}{\text { Probability of no restenosis, variable absent }}}$

Multivariate linear and logistic regression analyses were performed using SYSTAT software (System for Statistics, Evanston, Illinois) on clinical and angiographic variables with a $\mathrm{p}<0.15$ in the univariate analysis. Features with $<20$ observations were not included. A p value $<0.05$ was considered statistically significant.

\section{RESULTS}

Symptom recurrence after directional atherectomy: During the follow-up period, 175 patients $(67 \%)$ remained asymptomatic (Table I). Angiographic followup was available in 129 asymptomatic patients (74\%); 27 of them $(21 \%)$ developed restenosis. Of the 46 asymptomatic patients who did not undergo arteriography, $30(65 \%)$ had exercise treadmill tests suggestive of recurrent ischemia. Angiographic follow-up was also 


\begin{tabular}{|c|c|c|c|c|c|c|}
\hline & \multirow{2}{*}{\multicolumn{2}{|c|}{$\begin{array}{c}\begin{array}{r}\text { Residual Lumen } \\
\text { Diameter (mm) }\end{array} \\
\text { Coefficient }\end{array}$}} & \multirow{2}{*}{\multicolumn{2}{|c|}{$\frac{\text { Late Lumen Loss }(\mathrm{mm})}{\text { Coefficient }}$}} & \multirow{2}{*}{\multicolumn{2}{|c|}{$\begin{array}{c}\text { Restenosis } \\
(\geq 50 \% \text { diameter } \\
\text { stenosis) }\end{array}$}} \\
\hline & & & & & & \\
\hline & Univariate $p$ & Multivariate $\mathrm{p}$ & Univariate $p$ & Multivariate $p$ & $\begin{array}{l}\text { Univariate } \\
\qquad p\end{array}$ & $\begin{array}{c}\text { Multivariate } \\
\text { p }\end{array}$ \\
\hline \multicolumn{7}{|l|}{ Clinical factors } \\
\hline Male gender & $>0.15$ & - & $\begin{array}{c}0.020 \\
(0.530)\end{array}$ & $\begin{array}{c}0.020 \\
(0.466)\end{array}$ & 0.025 & 0.045 \\
\hline $\begin{array}{l}\text { History of } \\
\text { restenosis }\end{array}$ & $\begin{array}{c}0.002 \\
(-0.400)\end{array}$ & $\begin{array}{c}0.001 \\
(-0.468)\end{array}$ & $>0.15$ & - & 0.003 & $<0.001$ \\
\hline \multicolumn{7}{|c|}{ Angiographic factors } \\
\hline SVG location & $>0.15$ & - & $\begin{array}{c}0.038 \\
(0.549)\end{array}$ & $\begin{array}{c}0.008 \\
(0.627)\end{array}$ & 0.058 & 0.025 \\
\hline $\begin{array}{l}\text { Lesion length } \\
\geq 10 \mathrm{~mm} \\
\text { Procedural factors }\end{array}$ & $\begin{array}{c}0.020 \\
(-0.493)\end{array}$ & $\begin{array}{c}0.019 \\
(-0.425)\end{array}$ & $>0.15$ & - & 0.010 & 0.018 \\
\hline \multirow[t]{2}{*}{$\begin{array}{l}\text { Residual lumerl } \\
\text { diameter after } \\
\text { atherectomy }\end{array}$} & - & - & $\begin{array}{c}<0.001 \\
(0.657)\end{array}$ & $\begin{array}{c}<0.001 \\
(0.594)\end{array}$ & 0.106 & $>0.15$ \\
\hline & & $\begin{array}{l}\mathrm{R}=0.328 \\
\mathrm{SEE}=0.766 \\
\mathrm{p}<0.001\end{array}$ & & $\begin{array}{l}\mathrm{R}=0.503 \\
\mathrm{SEE}=0.988 \\
\mathrm{p}<0.001\end{array}$ & & $p<0.001$ \\
\hline
\end{tabular}

available in 83 of 87 patients (95\%) with recurrent angina after atherectomy; restenosis was found in $66(80 \%)$. Recurrent angina in the 17 patients $(20 \%)$ without angiographic restenosis was attributed to concomitant multivessel coronary artery disease or progression of other lesions not involved in the initial atherectomy procedure.

Overall restenosis after directional atherectomy: Angiographic restenosis developed in 93 lesions (44\%) after directional atherectomy. Restenosis rates were higher in restenotic lesions within saphenous vein grafts (11 of 14 [78\%: $95 \% \mathrm{CI}: 56$ to $100 \%]$ ) than in restenotic lesions within the left anterior descending ( 29 of 47 [62\%: $95 \%$ CI: 48 to $76 \%$ ]), left circumflex (3 of 7

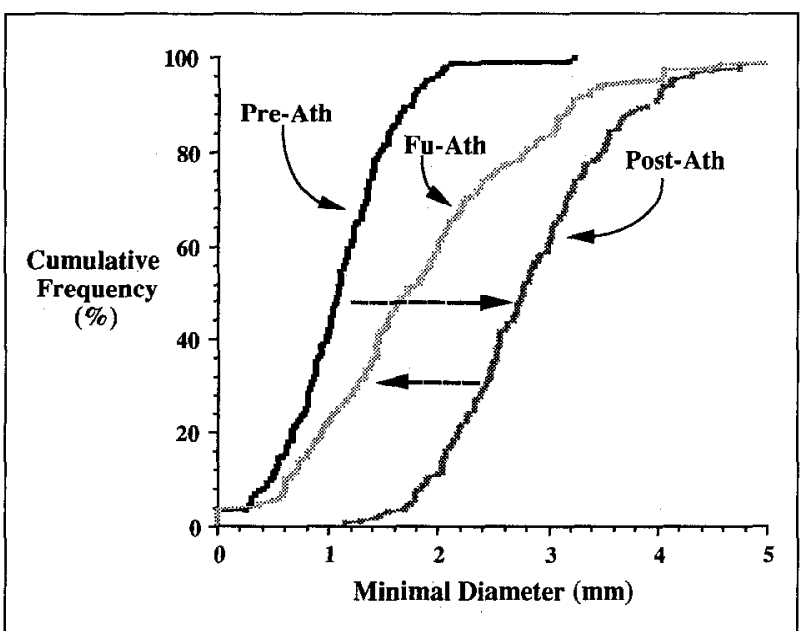

FGURE 1. Cumulative frequency distribution curve of quantitative coronary dimensions before (Pre-Ath), immediately after (Post-Ath) and late (Fu-Ath) after directional atherectomy. Early improvements in luminal dimensions (acute gain) are denoted by rightward amows and late lumen loss is denoted by the leftwand arrow.
[43\%: $95 \%$ CI: 6 to $80 \%$ ]) and right coronary (10 of 24 [42\%: $95 \%$ CI: 20 to 64\%]) arteries. Restenosis rates were lower in new lesions within the left anterior descending (15 of 55 [27\%: 95\% CI: 15 to $39 \%$ ]) and circumflex coronary ( 1 of 7 [14\%: $95 \%$ CI: 0 to $43 \%$ ]) arteries than in new lesions within the right coronary artery ( 10 of 23 [43\%: $95 \%$ CI: 23 to 63\%]) and saphenous vein grafts ( 4 of 10 [40\%: 95\% CI: 10 to $70 \%]$ ).

Factors affecting acute gain after directional atherectomy: In the subset of 193 patients in whom serial angiographic studies were available, minimal lumen diameters were significantly smaller in restenotic lesions (2.6 \pm 0.7 vs $3.0 \pm 0.8$ for new lesions; $\mathrm{p}=0.002)$ and in lesions $\geq 10 \mathrm{~mm}$ in length $(2.4 \pm 0.7$ vs $2.9 \pm 0.8 \mathrm{~mm}$ for lesions $<10 \mathrm{~mm}$ in length; $p=0.02)$. Acute gain was also less in restenotic lesions $(1.6 \pm 0.6$ vs $1.9 \pm 0.9 \mathrm{~mm}$ for new lesions; $\mathrm{p}=0.036$ ). Acute gain tended to be less in lesions $\geq 10 \mathrm{~mm}$ in length $(1.5 \pm 0.8$ vs $1.8 \pm 0.8 \mathrm{~mm}$ for lesions $<10 \mathrm{~mm}$ in length), but this difference was not statistically significant $(p=0.13)$. Residual lumen diameters and acute gain were not otherwise affected by gender, vessel location, or the presence of unfavorable morphologic features. Residual lumen diameters after atherectomy tended to be smaller in lesions with late restenosis, although this difference was not significant $(p=0.11)$. Differences in acute gain between the 2 groups did not achieve statistical significance (Table II). Restenosis developed in 19 of 47 lesions $(40 \%)$ with a residual minimal lumen diameter $\geq 3.5 \mathrm{~mm}$ immediately after atherectomy compared with 74 of 165 lesions (45\%) with a residual minimal lumen diameter $<3.5 \mathrm{~mm}$.

Predictors of late lumen loss after directional atherectomy: During the follow-up period, late lumen loss averaged $1.0 \pm 1.3 \mathrm{~mm}$ (Table II), resulting in a net lumen gain of $0.8 \pm 1.1 \mathrm{~mm}$ after directional atherec- 


\begin{tabular}{|c|c|c|c|}
\hline Restenosis & $\begin{array}{l}\text { Negative } \\
\text { No. }(\%)\end{array}$ & $\begin{array}{l}\text { Positive } \\
\text { No. }(\%)\end{array}$ & $\begin{array}{l}\text { Odds Ratio } \\
(95 \% \mathrm{Cl})\end{array}$ \\
\hline \multicolumn{4}{|l|}{ Clinical features } \\
\hline Age (year) & $57 \pm 11$ & $59 \pm 9$ & NA \\
\hline Male gender & $81(75)$ & $74(88)$ & $2.47(1.12-5.45)^{\star}$ \\
\hline Diabetes mellitus & $13(14)$ & $16(21)$ & $1.63(0.73-3.64)$ \\
\hline Unstable angina & $54(50)$ & $48(56)$ & $1.29(0.73-2.28)$ \\
\hline Restenotic lesion & $39(38)$ & $53(64)$ & $2.94(1.62-5.35) \dagger$ \\
\hline \multicolumn{4}{|l|}{ Angiographic features } \\
\hline Multivessel disease & $40(39)$ & $38(46)$ & $1.38(0.77-2.48)$ \\
\hline Bend $\geq 45^{\circ}$ & $7(6)$ & $8(9)$ & $1.52(0.53-4.36)$ \\
\hline Diffuse proximal disease & $8(7)$ & $15(16)$ & $2.62(1.06-6.51)^{*}$ \\
\hline Eccentricity & $63(54)$ & $44(50)$ & $0.84(0.48-1.47)$ \\
\hline Proximal tortuosity & $6(5)$ & $4(4)$ & $0.83(0.23-3.03)$ \\
\hline Lesion irregularity & $21(18)$ & $18(19)$ & $1.07(0.53-2.17)$ \\
\hline Calcium & $9(8)$ & $8(9)$ & $1.17(0.43-2.71)$ \\
\hline Bifurcation & $13(11)$ & $6(7)$ & $0.57(0.21-1.56)$ \\
\hline Thrombus & $5(4)$ & $8(9)$ & $2.19(0.69-6.94)$ \\
\hline Saphenous vein graft & $10(8)$ & $16(17)$ & $2.26(0.97-5.25) \neq$ \\
\hline Narrowing $\geq 10 \mathrm{~mm}$ & $5(4)$ & $15(17)$ & $4.50(1.59-12.91) \dagger$ \\
\hline \multicolumn{4}{|l|}{ Procedural factors } \\
\hline 7Fr device & $53(45)$ & $39(47)$ & $1.05(0.60-1.84)$ \\
\hline Device:artery ratio & $0.70 \pm 0.13$ & $0.72 \pm 0.12$ & NA \\
\hline Number specimens & $7 \pm 4$ & $8 \pm 6$ & NA \\
\hline Number passes & $13 \pm 7$ & $15 \pm 9$ & NA \\
\hline Balloon pressure (psi) & $40 \pm 11$ & $41 \pm 11$ & NA \\
\hline $\begin{array}{l}0.05 ; \uparrow p=0.01 ; \dagger p=0 \\
\text { bers and percentages repor } \\
\text { confidence interval; NA }=\end{array}$ & missing data. & & \\
\hline
\end{tabular}

tomy (Figure 1). In 117 lesions (55\%), lumen loss during the follow-up period exceeded $0.72 \mathrm{~mm}$. In 29 lesions (18\%), an improvement of $0.6 \pm 0.5 \mathrm{~mm}$ in minimal lumen diameter developed during the follow-up period.

Using multivariate linear regression analysis, late lumen loss was independently associated with the minimal lumen diameter immediately after directional atherectomy ( $p<0.001$ ), saphenous vein graft lesion location $(p=0.008)$ and male gender $(p=0.02)$ (Table III). Moreover, late lumen loss was independently associated with the residual percent diameter stenosis immediately after directional atherectomy $(R=0.420$; $\mathrm{SEE}=1.056 ; \mathrm{p}<0.001$ ) (Figure 2). Late lumen loss was not related to such procedural factors as the device:artery ratio, number of specimens retrieved, or the balloon pressure during dircctional atherectomy.

Risk factors for restenosis after directional atherectomy: The clinical, angiographic and procedural characteristics by restenosis status are presented in Table IV. Male gender, restenotic lesions, diffuse proximal disease, saphenous vein graft lesion location and lesions $\geq 10 \mathrm{~mm}$ in length imparted a twofold or greater risk of restenosis after directional atherectomy. Angiographic restenosis developed in 60 of 143 lesions (42\%) with $\geq 5$ specimens retrieved and in 23 of 57 lesions $(40 \%)$ with $<5$ specimens retrieved. Logistic regression analysis also revealed that restenotic lesions $(p<0.001)$, lesions $\geq 10 \mathrm{~mm}(p=0.018)$, saphenous vein graft lesion location $(\mathrm{p}=0.025)$ and male gender $(\mathrm{p}=0.045)$ were risk factors for angiographic restenosis (Table III). Other procedural factors, such as the atherectomy device size, number of specimens retrieved, balloon inflation pres- sure, or final percent diameter stenosis, were not significantly related to restenosis (Table IV).

\section{DIScussion}

The clinical and angiographic follow-up of 262 patients undergoing directional coronary atherectomy at 5 clinical centers is reported. During the 4- to 6-month follow-up period, angiographic restenosis developed in 93 of 212 lesions (44\%) with late angiography. Several clinical and angiographic factors affecting both acute gain and late lumen loss after directional atherectomy were associated with restenosis, suggesting that, similar to

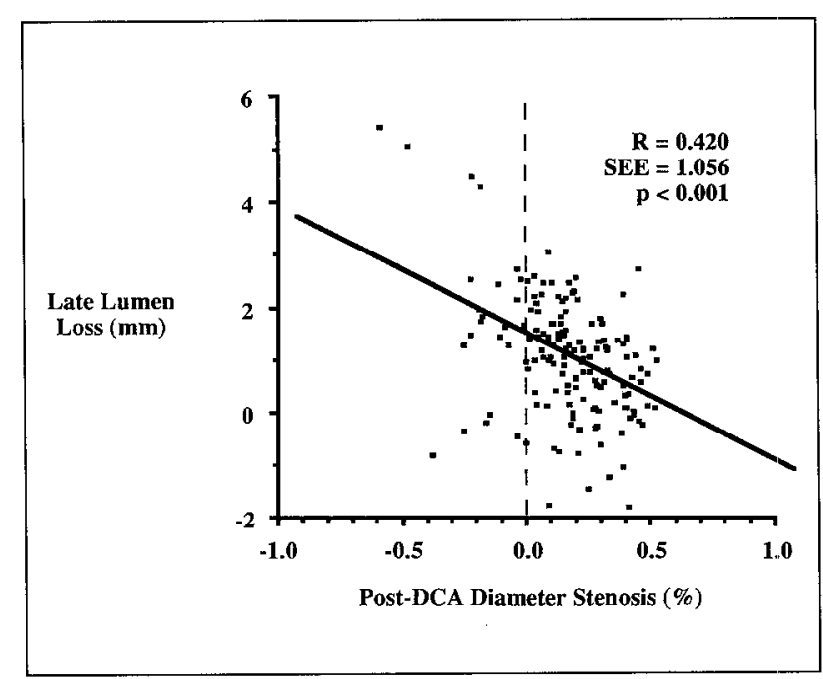

FIGURE 2. Inverse relation between minimal lumen diameter immediately after directional atherectomy (Post-DCA) and late lumen loss. 
coronary angioplasty, the mechanism of restenosis after directional atherectomy is multifactorial.

Acute gain and late lumen loss after directional atherectomy: Nonrandomized series suggest that investigational devices may yield more favorable initial angiographic results than those obtained after balloon angioplasty, ${ }^{9,10}$ although the relation of these early findings to late angiographic outcome has not been studied until recently. Using 3 investigational angioplasty devices, Kuntz et al ${ }^{11}$ showed that new devices allow large initial gains in lumen diameter $(2.6,2.2$ and 2.0 $\mathrm{mm}$ for intracoronary stenting, directional atherectomy and laser balloon angioplasty, respectively). However, late lumen loss averaged $1.0 \mathrm{~mm}$ with each of the devices during the follow-up period, a lumen loss much greater than the 0.4 to $0.5 \mathrm{~mm}$ loss historically noted after balloon angioplasty. ${ }^{15,16}$ Given similar degrees of late lumen loss with each device, variable restenosis rates were attributed to different degrees of acute gain initially achieved with each: the lowest rates were noted with intracoronary stents (19\%), intermediate rates with directional atherectomy (31\%), and highest rates with laser balloon angioplasty $(50 \%)$. The authors concluded that the initial gains in coronary dimensions achieved with new angioplasty devices were partially negated by greater degrees of late lumen loss resulting from intimal hyperplasia and vascular recoil. Nevertheless, because the initial gains were generally of greater magnitude than late lumen loss, the ultimate restenosis rate was determined by the initial gain achieved immediately after the intervention. ${ }^{11}$

In the present report, an acute gain of $1.8 \pm 0.9 \mathrm{~mm}$ and residual lumen diameter of $2.9 \pm 0.9 \mathrm{~mm}$ were obtained immediately after directional atherectomy. Acute gain and residual lumen diameters were smaller in restenotic lesions and in lesions $\geq 10$ in length, possibly accounting for the greater propensity for restenosis noted in these lesion subsets. The residual lumen diameter immediately after atherectomy tended to inversely relate to restenosis $(\mathrm{p}=0.11)$, i.e., larger residual diameters had lower restenosis rates. Differences in lesion selection may account for the larger acute gain $(2.2 \mathrm{~mm})$ and lower restenosis rates $(31 \%)$ in the series by Kuntz et al, ${ }^{11}$ although reference segment diameters, residual lumen diameters and residual percent diameter stenoses were similar in the 2 reports, suggesting an equally aggressive approach to atheroma resection. Dissimilar angiographic methods (digital calipers vs an automated edge-detection algorithm in the present series) may also have contributed to the differences in acute gain in the 2 studies.

Varying degrees of intimal hyperplasia and elastic recoil occur in most patients after investigational device use, culminating in clinical restenosis in some patients. In the present series, late lumen loss averaged $1.0 \pm 1.3$ $\mathrm{mm}$ after directional atherectomy, which is more than the 0.4 to $0.5 \mathrm{~mm}$ lumen loss reported after balloon angioplasty. ${ }^{15,16}$ Our data suggest that late lumen loss is not constant after investigational device use, but varies in association with certain clinical, angiographic and procedural factors. Late lumen loss was greater with male gender and saphenous vein graft lesion location, features that have also been related to lumen loss after coronary angioplasty. ${ }^{17,18}$ It was also directly related to the residual lumen diameter and inversely related to the percent diameter stenosis immediately after the procedure (Figure 2). These findings suggest that more aggressive atheroma resection may result in more pronounced intimal hyperplasia and elastic recoil during the follow-up period. Notably, the magnitude of late lumen loss $(1.0 \mathrm{~mm})$ was less than the magnitude of acute lumen gain $(1.8 \mathrm{~mm})$, resulting in a net improvement of $0.8 \mathrm{~mm}$ in minimal lumen diameter late after the procedure.

Incidence and correlates of restenosis after directional atherectomy: Depending on the definition used, restenosis rates of 30 to $50 \%$ have been reported after directional atherectomy. ${ }^{7,8,11}$ Restenosis, defined as a visually determined diameter stenosis $\geq 50 \%$ or $>50 \%$ loss of the initial gain at the time of follow-up arteriography, developed in 37 of 74 lesions $(50 \%)$ in 1 series. $^{8}$ Increased age, the presence of diabetes mellitus, and lesions within saphenous vein grafts were associated with higher rates of restenosis, although differences in restenosis rates between restenotic and new lesions (54 vs $46 \%)$ did not reach statistical significance. Subintimal tissue resection increased the restenotic rate for saphenous vein grafts, suggesting that the extent of intimal hyperplasia may be related to the depth of resection within saphenous vein grafts. In another series, restenosis, defined as caliper-determined diameter stenosis $>60 \%$, developed in $30 \%$ of 67 lesions 6 months after directional atherectomy. ${ }^{7}$ In the present series, an overall restenosis rate of $43 \%$ is reported. It was highest in restenotic lesions within saphenous vein grafts $(78 \%)$, while lowest in new lesions within the left anterior descending $(27 \%)$ and left circumflex (14\%) coronary arteries.

Our data suggest that at least 2 factors contribute to restenosis after directional atherectomy: a suboptimal initial gain in lumen diameter immediately after atherectomy and excessive late lumen loss. Smaller residual lumen diameters were obtained immediately after directional atherectomy in restenotic lesions and in lesions $>10 \mathrm{~mm}$ in length. More pronounced late lumen loss occurred in men and in lesions involving saphenous vein grafts.

Study limitations: Pathologic specimens were not available for histologic review and the impact of subintimal resection on late lumen loss and restenosis was not assessed in this report. The clinical importance of resection of normal vessel wall is unclear, ${ }^{7,19,20}$ and further study will be needed to determine the optimal depth of cut after directional atherectomy. Moreover, despite the identification of predictive factors associated with late lumen loss after directional atherectomy, the explanatory ability of these factors is modest $(\mathrm{R}=0.503)$. Undoubtedly, other unidentified factors may also be important correlates of restenosis after directional atherectomy. Finally, our findings do not lend insight into the mechanisms of late lumen loss after directional atherectomy, i.e., vascular recoil versus intimal hyperplasia. Discrim- 
ination between these factors may be important in further modification of the lesion-specific use of investigational devices.

Acknowledgment: We gratefully appreciate the statistical assistance of $\mathrm{Ya}$ chien Chuang, $\mathrm{PhD}$, in the preparation of this manuscript.

\section{APPENDIX}

University of Michigan, Ann Arbor, Michigan: Eric Topol, MD, Stephen Ellis, MD, Jeffrey J. Popma, David Muller, MBBS; Emory University, Atlanta, Georgia: Spencer King, MD, John Douglas, MD, Nicholas Lembo, MD, Ziyad Ghazzal, MD; St. Vincent's Hospital, Indianapolis, Indiana: Cass A. Pinkerton, MD; Christ Hospital, Cincinnati, Ohio: Dean Kereiakes, $\mathrm{MD}$, Charles Abbottsmith, MD; Cleveland Clinic, Cleveland, Ohio: Patrick Whitlow, MD, Jay Hollman, MD; Angiographic Core Laboratory, Washington, D.C.: Nicoletta B. DeCesare, MD, Jeffrey J. Popma, MD, Stephen G. Ellis, MD.

\section{REFERENCES}

1. Schatz RA, Baim DS, Leon M, Ellis SG, Goldberg S, Hirschfield JW, Cleman MW, Cabin HS, Walker C, Stagg J, Buchbinder M, Teirstein PS, Topol EJ, Sav age M, Perez JA, Curry RC, Whitworth H, Sousa JE, Tio F, Almagor Y, Ponder R, Penn IM, Leonard B, Levine SL, Fish RD, Palmaz JC. Clinical experience with the Palmaz-Schatz coronary stent. Initial results of a multicenter study. Circulation 1991;83:148-161.

2. Karsch KR, Haase KK, Voelker W, Baumbach A, Mauser M, Seipel L. Percutaneous coronary excimer laser angioplasty in patients with stable and unstable angina pectoris: acute results and incidence of restenosis at 6-month follow-up. Circulation 1990;81:1849-1859.

3. Hinohara T, Robertson GC, Selmon MR, Simpson JB. Directional coronary atherectomy. I Inv Cardiol 1990;2:217-226.

4. Reis GJ, Pomerantz RM, Jenkins RD, Kuntz RE, Baim DS, Diver DJ, Schnit SJ, Safian RD. Laser balloon angioplasty: clinical, angiographic and histologic results. I Am Coll Cardiol 1991;18:193-202.

5. Teirstein PS, Warth DC, Haq N, Jenkins NS, McCowan LC, Aubanel-Reidel P, Morris N, Ginsburg R. High speed rotational coronary atherectomy for patients with diffuse coronary artery disease. I Am Coll Cardiol 1991;18:1694-1701.

6. Safian RD, Gelbfish JS, Einy RE, Schnitt SJ, Schmidt DA, Baim DS. Coronary atherectomy. Clinical, angiographic, and histologic findings and observations regarding potential mechanisms. Circulation 1990;82:69-79.
7. Garratt KN, Holmes DR Jr, Bell MR, Bresnahan JF, Kaufmann UP, Vlietstra RE, Edwards WD. Restenosis after directional coronary atherectomy: Differences between primary atheromatous and restenosis lesions and influence of subintimal tissue resection. $J$ Am Coll Cardiol 1990;16:1665-1671.

8. Pepine CJ, Hirshfield JW, Macdonald RG, Henderson MA, Bass TA, Goldberg S, Savage MP, Vetrovec G, Cowley M, Taussig AS, Whitworth HB, Margolis JR, Hill JA, Bove AA, Jugo R. A controlled trial of corticosteroids to prevent restenosis after coronary angioplasty. Circulation 1990;81:1753-1761.

9. Rowc MH, Hinohara T, White NW, Robertson GC, Selmon MR, Simpson JB. Comparison of dissection rates and angiographic results following directional coronary atherectomy and coronary angioplasty. Am J Cardiol 1990;66:49-53.

10. Muller DWM, Ellis SG. Debowey DL, Topol EJ. Quantitative angiographic comparison of the immediate success of coronary angioplasty, coronary atherectomy and endoluminal stenting. Am J Cardiol 1990;66:938-942.

11. Kuntz RE, Safian RD, Levine MJ, Reis GJ, Diver DJ, Baim DS. Novel approach to the analysis of restenosis after the use of three new coronary devices. $J$ Am Coll Cardiol 1992;19:1493-1499.

12. Popma JJ, DeCesare NB, Holmes DR, Pinkerton CA, Whitlow P, King SB Ghazzal ZMB, Kereiakes DJ, Tupol EJ, Garratt KN, Ellis SG. Clinical, angiographic, and procedural correlates of quantitative coronary dimensions following directional coronary atherectomy. J Am Coll Cardiol 1991;18:1183-1189.

13. Ellis SG, De Cesare NB, Pinkerton CA, Whitlow P, King SB, Ghazzal ZMB, Kereiakes DJ, Popma JJ, Menke KK, Topol EJ, Holmes DR. Relation of stenosis morphology and clinical presentation to the procedural results of directional coronary atherectomy. Circulation 1991;84:644-653.

14. Mancini GBJ, Simon SB, McGillem MJ, LeFree MT, Friedman HZ, Vogel RA. Automated quantitative coronary arteriography: morphologic and physiologic validation in vivo of a rapid digital angiographic method. Circulation 1987;75: $452-460$.

15. Nobuyoshi M, Kimura T, Nosaka H, Mioka S, Ueno K, Yokoi H, Hamasak N, Horiuchi H, Ohishi H. Restenosis after successful percutaneous transluminal coronary angioplasty: serial angiographic follow-up of 229 patients. J Am Coll Cardiol $1988 ; 12: 616-623$

16. Sernys PW, Luijten HE, Beatt KJ, Geuskens R, DeFeyter PJ, van den Brand M, Reiber JHC, ten Katen HJ, van Es GA. Hugenholtz PG. Incidence of restenosis after successful coronary angioplasty: a time related phenomenon. A quantitative angiographic study in 342 consecutive patients at $1,2,3$, and 4 months. $\mathrm{Cir}$ culation 1988;77:361-371.

17. Holmes DR, Vlietstra RE, Smith HC, Vetrovec GW, Kent KM, Cowley MJ, Faxon DP, Gruentzig AR, Kelsey SF, Detre KM, van Raden MJ, Mock MB. Restenosis after percutaneous transluminal coronary angioplasty (PTCA): a report from the PTCA registry of the National IIcart, Lung, and Blood Institute. Am J Cardiol 1984;53:77C-81C.

18. Hirschfeld JW, Schwartz JS, Jugo R, MacDonald RG, Goldberg S, Savage MP, Bass TA, Vetrovec G, Cowley M, Tauddig AS, Whitworth HB, Margolis JR, Hill JA, Pepine CJ. Restenosis after coronary angioplasty: a multivariate statistical model to relate lesion and procedure variables to restenosis. I Am Coll Cardiol 1991; 18:647-656

19. Kuntz RE, Selmon M, Robertson G, Schnitt S, Safian R. Excision of deep wall components by directional atherectomy does not increase restenosis (abstr). Circulation 1991;84(suppl II):П-81.

20. Yakubov SJ, Dick RJ, Haudenschild CC, Rosenschein U. Deep tissue retrieval with coronary atherectomy is paradoxically associated with less restenosis (abstr) Circulation 1991;84(suppl II):II-81. 